\title{
SIRT3 regulates bronchial epithelium apoptosis and aggravates airway inflammation in asthma
}

\author{
JIE SONG and JINXIANG WANG \\ Department of Pulmonary and Critical Care Medicine, Beijing Luhe Hospital,
Capital Medical University, Tongzhou, Beijing 101100, P.R. China
}

Received January 28, 2021; Accepted October 20, 2021

DOI: $10.3892 / \mathrm{mmr} .2022 .12660$

\begin{abstract}
Sirtuin (SIRT)3 is closely related to inflammation and apoptosis and studies have described this relationship, including in the lungs. However, the expression of SIRT3 and its effect on apoptosis and inflammation in bronchial tissue in asthma remains to be elucidated. The present study found that SIRT3 expression decreased in the bronchial tissues of asthmatic mice and its upregulation could not only reduce increased bronchial epithelial cells apoptosis in the asthmatic mice but also significantly decreased the elevated expression of cytokines (TNF- $\alpha$, IL-4, IL-5 and IL-13) in bronchoalveolar lavage fluid. Further study found that SIRT3 overexpression significantly decreased apoptosis-related protein expression ( $\mathrm{Bax} / \mathrm{Bcl} 2$ ratio and caspase 3 activity) and oxidative injury. In vitro, SIRT3 regulated oxidative stress-induced bronchial epithelial cell (16HBE) apoptosis and cytokine expression. In conclusion, SIRT3 expression decreased in bronchial tissues of asthmatic mice and the upregulation of SIRT3 expression could reduce the apoptosis of bronchial epithelium and airway inflammation. It was concluded that SIRT3 might be a potential target in asthma treatment.
\end{abstract}

\section{Introduction}

Bronchial asthma (asthma) is the most common chronic respiratory disease in children. There are $\sim 300$ million individuals with asthma worldwide and the number of patients is increasing year by year (1). In China 30 million individuals suffer from asthma and the prevalence rate is $1-4 \%$ (2). Asthma is a chronic inflammatory disease characterized by airway hyperresponsiveness, inflammatory cell infiltration, excessive mucus production and airway remodeling and it can be induced by respiratory tract infection, allergen exposure, strenuous

Correspondence to: Dr Jie Song, Department of Pulmonary and Critical Care Medicine, Beijing Luhe Hospital, Capital Medical University, 82 Xinhuanan Road, Tongzhou, Beijing 101100, P.R. China

E-mail:wasongjie@ccmu.edu.cn

Key words: sirtuin 3, apoptosis, inflammation, asthma exercise, climate change and other factors $(3,4)$. Although the specific pathogenesis of asthma remains to be elucidated, airway inflammation is recognized as the most fundamental pathological change in its pathogenesis. Therefore, the inhibition of inflammation is an important strategy for asthma therapy. Glucocorticoids, among the most effective drugs for controlling airway inflammation, are widely used to treat asthma $(3,4)$. However, long-term use of glucocorticoid treatment can cause a number of side effects, such as increased blood pressure, hyperglycemia, edema, osteoporosis, ulcer formation and weight gain (5). Therefore, it is essential to study the molecular mechanism of airway inflammation in asthma.

Airway epithelial cells are mainly composed of secretory and ciliated cells and they serve a critical role in the body's resistance to pathogenic microorganisms and the removal of foreign substances, such as dust particles $(6,7)$. In asthmatic patients, the presence of airway inflammation leads to airway epithelial damage, including airway epithelial apoptosis, shedding and airway structure remodeling and these changes can weaken or cause the loss of the original function of the airway epithelium $(8,9)$. Airway epithelium damage leads to the weakening of its physical barrier function, thereby increasing the risk of infection, forming a vicious circle that feeds on itself $(8,9)$. Studying the apoptosis and inflammatory mechanisms of airway epithelial cells is therefore crucial for the treatment of asthma.

Sirtuins are a protein family that regulate cell health and serve a key role in regulating cell homeostasis (10). They are considered a new target for the treatment of bronchial inflammation (11). Sirtuin (SIRT) 3 is a member of the sirtuin family that promotes longevity in a number of organisms, regulates inflammation through the modulation of mitochondrial function (12) and improves the antioxidant defense mechanisms $(13,14)$. Although no studies of SIRT3 in asthma are reported, the sirtuin protein family serves an essential role in chronic obstructive pulmonary disease (15); SIRT3 can not only resist lung injury by resisting inflammation (16) and oxidation (17) but also protects bronchial epithelial cells by inhibiting oxidative stress (18) and autophagy (19). In addition, SIRT1, an upstream molecule that regulates the expression of SIRT3, is related to the severity of asthma $(20,21)$. A study by Colley et al (22) also found that defective SIRT1 increases IL-4 expression through acetylation of GATA-3 in patients with severe asthma. Combined with the evidence by Liu et al (12) 
that SIRT1 suppresses inflammation by promoting SIRT3 expression, it was hypothesized that SIRT3 also served an essential role in asthma.

SIRT3 is also an apoptosis-related protein (23) and aberrant apoptosis of airway epithelial cells is also a contributing factor in development of asthma $(24,25)$. Previous studies have found that downregulation of SIRT3 promotes the apoptosis of alveolar epithelial cells (26) and EC9706 cells (27). Studies have also shown that SIRT3 protects tumor cells against apoptosis under unfavorable environments, such as hypoxia (28), oxidized low-density lipoprotein (29) and high glucose levels (30). However, the expression of SIRT3 and its effect on apoptosis and bronchial inflammation in asthma remains to be elucidated. The present study attempted to investigate the role of SIRT3 in epithelial cells apoptosis induced by oxidative stress $\left(\mathrm{H}_{2} \mathrm{O}_{2}\right)$ and the effect of SIRT3 overexpression on inflammation and airway epithelial structural integrity in asthmatic mice.

\section{Materials and methods}

Animals and experimental asthma model. The animal experiment was performed according to the protocols approved by the Beijing Luhe Hospital, Capital Medical University (approval no. 2021-LHKY-055-02). A total of 28 female C57BL/6 mice (age, 5-6 weeks; weight, 18-22 g) were used in the present study. Mice were purchased from Shanghai Lingchang Biological Technology Co., Ltd. and were kept at $\sim 20-26^{\circ} \mathrm{C}, 40 \%$ relative humidity with $12 \mathrm{~h}$ light/dark cycles. After being housed under conventional conditions for one week prior to any experiments, 21 mice were used in the establishment of the asthma model, as illustrated in Fig. 1A (31). In brief, $200 \mu \mathrm{l}$ of sensitizing fluid [containing $100 \mu \mathrm{g}$ of ovalbumin (OVA) and $20 \mathrm{mg}$ of Alum] was administered by intraperitoneal (i.p.) injection on day 0 and 14 . From day 21, mice were given $40 \mathrm{ml}$ of $2 \%$ OVA atomized solution through spray inhalation for $30 \mathrm{~min} / \mathrm{day}$ for seven days. Control mice were given the same amount of saline solution at the same time. All mice were randomly distributed into 4 groups (7 mice/group): i) Control group; healthy mice; ii) Asthma group; experimental asthma mice model without any treatment; iii) Asthma + DEX group: experimental asthma mice model treated with $1 \mathrm{mg} / \mathrm{Kg}$ dexamethasone (DEX; cat. no. D4902; MilliporeSigma), i.p., for 7 days during the last week of OVA inhalation (32) and iv) Asthma + Ad-m-SIRT3 group; experimental asthma mice model infected with mice SIRT3 adenovirus (cat. no. AAV-272009; Vector BioLabs).

Lung resistance (LR) assessment and BALF collection. After $48 \mathrm{~h}$ from the last atomization with OVA, an AniRes2005 pulmonary function meter (Beijing Beilanbo Technology Co., Ltd.) was used to measure the lung resistance of mice to evaluate the experimental asthma model: Briefly, following intratracheal intubation, normal saline nebulization was used to determine basic lung resistance. After $2 \mathrm{~min}$ of rest, acetylcholine solutions of $50,20,10$ and $5 \mathrm{mg} / \mathrm{ml}$ were nebulized for 2 min and lung resistance was subsequently determined. After assessing the lung function, the mice were euthanized by exposure to $\mathrm{CO}_{2}(20-30 \%$ of chamber volume per min) after being anesthetized with sodium pentobarbital $(50 \mathrm{mg} / \mathrm{kg}$ i.p.) and the trachea was exposed. A $5 \mathrm{ml}$ sterile syringe was then used to inject $2 \mathrm{ml}$ of sterile PBS into the trachea and then the
PBS solution was recovered. This process was repeated twice. The resultant collected cells in the PBS were bronchoalveolar lavage fluid (BALF). For cell count, cells were centrifuged at $500 \mathrm{x} \mathrm{g}$ for $5 \mathrm{~min}$ at room temperature for cell collection, resuspended in PBS and the cell suspension was smeared on a glass slide. Wright's Giemsa staining solution (cat. no. G3990; Beijing Solarbio Science \& Technology Co., Ltd.) was used for cell staining for $1 \mathrm{~min}$ at room temperature and the cells were counted under an optical light microscope.

Infection of adenovirus in mice and 16HBE cells. After being anesthetized with sodium pentobarbital ( $50 \mathrm{mg} / \mathrm{kg}$ i.p.), $4 \times 10^{5} \mathrm{PFU} / 40 \mu 1$ mice SIRT3 adenovirus (cat. no. AAV-272009, Vector Biolabs) was administered by nasal spray inhalation and the mice in the control group were infected with equivalent empty adenovirus, as previously described $(33,34)$. After being infected with the adenovirus for $48 \mathrm{~h}$, the mice were sacrificed to collect the bronchial tissues.

For adenovirus infection of 16HBE cells to knockdown or overexpress SIRT3, 1.0x $10^{6}$ 16HBE cells were first seeded in a 6-well cell culture plate and cultured for $12 \mathrm{~h}$ at $37^{\circ} \mathrm{C}$. To infect $16 \mathrm{HBE}$ cells $1 \times 10^{10} \mathrm{PFU} / 100 \mu \mathrm{l}$ SIRT3-AAV (cat. no. AAV-223017; Vector Biolabs) or SIRT3-short hairpin (sh)RNA adenovirus (cat. no. shAAV-272009; Vector Biolabs) were used to infect $16 \mathrm{HBE}$ cells and $16 \mathrm{HBE}$ cells were also infected with equivalent empty adenovirus [NC-shRNA (non-targeting sequence) (cat. no. shAAV-272009; Vector Biolabs) or NC-AAV (cat. no. shAAV-223017; Vector Biolabs)] as a negative control. After being infected with the adenovirus for $48 \mathrm{~h}$ at $37^{\circ} \mathrm{C}$, the cells were collected for analysis.

Reverse transcription-quantitative (RT-q) PCR. An RNA extraction kit (cat. no. RC101-01, Vazyme Biotech Co., Ltd.) was used to extract the total RNA from cells $\left(2 \times 10^{6}\right)$ and tissues according to the manufacturer's protocol. Total RNA was reverse transcribed into cDNA using the PrimeScript RT reagent (cat. no. RR047A; Takara Bio, Inc.) according to the manufacturer's protocol. Next, $20 \mu \mathrm{l}$ of RT-qPCR system was prepared, as described in the qPCR master mix kit instructions (cat. no. A6001; Promega Corporation) and the following thermocycling conditions were used: $95^{\circ} \mathrm{C}$ for $2 \mathrm{~min}$; and 40 cycles at $95^{\circ} \mathrm{C}$ for $5 \mathrm{sec}$ and $65^{\circ} \mathrm{C}$ for $15 \mathrm{sec}$. The relative expression of the genes was calculated using the $2^{-\mathrm{DDC}}$ method (35). $\beta$-actin was used as a loading control. The primers used for qPCR analysis were: SIRT3-F: 5'-GGCTCTATACACAGA ACATCGAC-3', SIRT3-R: 5'-TAGCTGTTACAAAGGTCC CGT-3'; TNF- $\alpha$-F: 5'-GACGTGGAACTGGCAGAAGAG-3', TNF- $\alpha$-R: 5 '-TTGGTGGTTTGTGAGTGTGAG-3'; IL-4-F: 5'-ATCATCGGCATTTTGAACGAGG-3', IL-4-R: 5'-TGC AGCTCCATGAGAACACTA-3'; IL-5-F: 5'-TCAGGGGCT AGACATACTGAAG-3', IL-5-R: 5'-CCAAGGAACTCTTGC AGGTAAT-3'; IL-13-F: 5'-CAGCCTCCCCGATACCAA AAT-3', IL-13-R: 5'-GCGAAACAGTTGCTTTGTGTAG-3'; $\beta$-actin-F: 5'-AGGGAAATCGTGCGTGACAT-3', $\beta$-actin-F: 5'-GCCTCAGGAGTTTTGTCACCT-3'. These experiments were repeated three times.

Western blot analysis. Total protein was extracted from tissues using a Tissue Protein Extraction Reagent (cat. no. 78510; Thermo Fisher Scientific, Inc.) and a BCA kit (cat. no. 23227; 

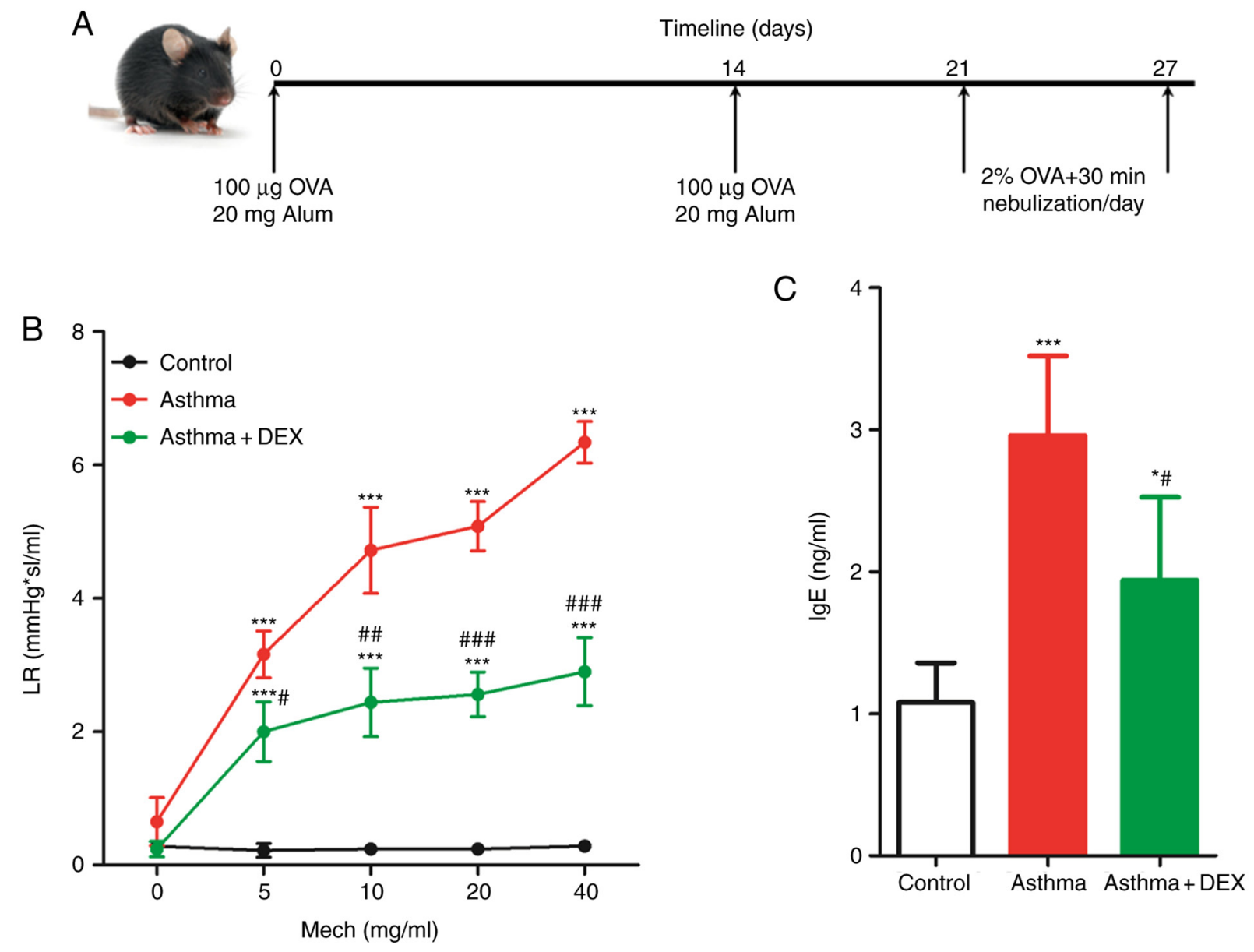

Figure 1. Establishment and evaluation of asthma mouse models. (A) Diagram of allergen immunization/challenge protocol. (B) The LR of each group was measured by invasive pulmonary function. (C) Total IgE in serum of each group was detected by ELISA. There were seven mice in each group, the data were shown as mean $\pm \mathrm{SD}$ and the $\mathrm{P}$-value was calculated by calculated by post-hoc comparisons. ${ }^{*} \mathrm{P}<0.05$ and ${ }^{* * *} \mathrm{P}<0.001$ vs. control; ${ }^{*} \mathrm{P}<0.05,{ }^{\# \# /} \mathrm{P}<0.01$ and

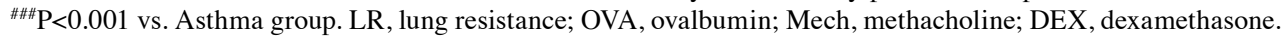

Thermo Fisher Scientific, Inc.) was used to determine the protein concentration. Then, $50 \mu \mathrm{g}$ total protein was analyzed using a $10 \%$ SDS-PAGE. After transferring to PVDF membranes (cat. no. LC2002; Thermo Fisher Scientific, Inc.) blocking was performed using $5 \%$ skimmed milk powder for $1 \mathrm{~h}$ at room temperature. The membranes were subsequently probed with primary antibodies against SIRT3 (1:1,000; cat. no. 2627; Cell Signaling Technology, Inc.), Bax (1:2,000; cat. no. ab32503; Abcam), Bcl2 (1:2,000; cat. no. ab196495; Abcam) and $\beta$-actin (1:4,000; cat. no. AF5001; Beyotime Institute of Biotechnology) at $4^{\circ} \mathrm{C}$ overnight. Subsequently, PVDF membranes were probed with goat anti-rabbit IgG heavy chain \& light chain (H\&L) HRP $(1: 2,000$; cat. no. ab6721; Abcam) or goat anti-mouse IgG H\&L HRP (1:2,000; cat. no. ab6789; Abcam) secondary antibodies for $1 \mathrm{~h}$ at room temperature. The proteins were visualized with an ECL solution (cat. no. WBKLS0100; Beijing Xinjingke Biotechnologies Co., Ltd.), followed by densitometry analysis using ImageJ v3.0 (National Institutes of Health). $\beta$-actin was used as control.

Immunohistochemistry staining of SIRT3. The expression of SIRT3 was detected in bronchial tissues using immunohistochemistry staining. Briefly, the bronchial tissues were harvested and fixed using 4\% paraformaldehyde (cat. no. P1110; Beijing Solarbio Science \& Technology Co., Ltd.) at $4^{\circ} \mathrm{C}$ overnight. Then histological paraffin sections $(5 \mu \mathrm{m})$ were made after being embedded in paraffin and procedurally dehydrated (tissues were placed in 30, 50, 70, 80, 95 and 100\% ethanol for $1 \mathrm{~h}$ at room temperature). There were seven mice in each group and $\geq 10$ histological sections were prepared for each animal. The bronchial sections were incubated overnight at $4^{\circ} \mathrm{C}$ with the anti-SIRT3 antibody (1:500; cat. no. 2627; Cell Signaling Technology, Inc.). After a mild wash with PBS buffer, the bronchial sections were incubated with HRP-conjugated goat anti-rabbit antibody (1:2,000; cat. no. ab6721; Abcam) for $1 \mathrm{~h}$ at room temperature. The peroxidase activity was assessed via a 2 min reaction at room temperature with diaminobenzidine (DAB). The bronchial tissue sections were further counterstained with hematoxylin for 2 min at room temperature and images captured under a bright-field light microscope (Olympus BX51; Olympus Corporation).

TUNEL staining. To determine the apoptosis in the bronchial tissues, TUNEL staining was used as described previously (36). In brief, the mice bronchial tissue sections were fixed with $4 \%$ paraformaldehyde for $24 \mathrm{~h}$ at $4^{\circ} \mathrm{C}$ and were embedded in paraffin. Subsequently the samples were procedurally 
dehydrated (tissues were placed in 30, 50, 70, 80, 95 and 100\% ethanol for $1 \mathrm{~h}$ at room temperature) and sectioned at $5 \mu \mathrm{m}$. After dewaxing and hydrating, tissue sections were incubated with proteinase $\mathrm{K}$ to permeate the cells for $30 \mathrm{~min}$ at $37^{\circ} \mathrm{C}$. Next, the sections were incubated with the TUNEL reaction solution for $1 \mathrm{~h}$ at $37^{\circ} \mathrm{C}$ and then color development was achieved with DAB solution for $30 \mathrm{~min}$ at room temperature. The TUNEL Cell Apoptosis Detection kit (cat. no. TA201-02; TransGen Biotech Co., Ltd.) was used.

Caspase-3 activity measurement. Apoptosis was quantified by the caspase- 3 activity measurement using the Ac-DEVD-7-Amino-4-trifluoromethylcoumarin (AFC) caspase-3 Fluorogenic Substrate (cat. no. 556574; BD Pharmingen; BD Biosciences) according to the manufacturer's instructions. Briefly, bronchial tissues from the control or asthma mice were lysed on ice. After centrifugation $\left(12,000 \mathrm{x} \mathrm{g}\right.$ for $10 \mathrm{~min}$ at $\left.4^{\circ} \mathrm{C}\right)$, the supernatants were collected and the protein concentration was quantified using the BCA method. A total of $50 \mu \mathrm{g}$ of proteins was pipetted and mixed with the assay buffer supplemented with $10 \mathrm{mM}$ dithiothreitol (DTT). The fluorescence emission of the AFC $(400 \mathrm{~nm})$ was measured via the Spectra Max-Plus Microplate Spectrophotometer (Molecular Devices, LLC). The caspase-3 activity was expressed as nmol $\mathrm{AFC} / \mathrm{h} / \mathrm{mg}$ protein.

Detection of cytokines and serum immunoglobulin (Ig)E. The concentration of TNF- $\alpha$, IL-4, IL-5 and IL-13 in bronchoalveolar lavage fluid (BALF) and serum IgE from mice were evaluated by ELISA kits as described in the manufacturer's instructions. The ELISA kits were: TNFa (cat. no. ab236712; Abcam), IL-4 (cat. no. ab100710; Abcam), IL-5 (cat. no. ab204523; Abcam), IL-13 (cat. no. ab100700; Abcam) and mice IgE (cat. no. ab157718; Abcam).

Detection of reactive oxygen species (ROS), glutathione $(G S H)$, superoxide dismutase (SOD), glutathione peroxidase (Gpx) and malondialdehyde (MDA). Homogenates were prepared with $50 \mathrm{mg}$ of fresh bronchial tissue and the supernatant collected following bronchial tissue homogenate centrifugation $\left(12,000 \mathrm{xg}, 4^{\circ} \mathrm{C}, 10 \mathrm{~min}\right)$. Then, a ROS Detection kit (cat. no. S0058; Beyotime Institute of Biotechnology) was used to quantify the ROS levels. A GSH detection kit (cat. no. S0058; Beyotime Institute of Biotechnology) was used to detect the GSH levels. In addition, a SOD assay kit (cat. no. S0101S; Beyotime Institute of Biotechnology) was used to detect the SOD levels and an MDA assay kit (cat. no. S0101S; Beyotime Institute of Biotechnology) was used to detect the MDA levels. Finally, a Gpx assay kit (cat. no. S0058; Beyotime Institute of Biotechnology) was used to detect the levels of Gpx. All these assays were performed as according to the manufacturer's protocols.

Cell treatment and apoptosis assay. $16 \mathrm{HBE}$ cells $\left(1.5 \times 10^{6}\right)$ were seeded in the 6-well cell culture plate and cultured for $12 \mathrm{~h}$. After stimulating them with $0,100,200$, or $400 \mu \mathrm{mol} / 1$ $\mathrm{H}_{2} \mathrm{O}_{2}$ for $12 \mathrm{~h}$, the cells were collected and washed twice with cold-PBS buffer, then an Annexin V-PE/7-AAD Apoptosis Detection kit (cat. no. A213-01; Vazyme) was used to evaluate the apoptosis by flow cytometry (CytoFLEX S;
Beckman Coulter, Inc.). In brief, cells were stained for $20 \mathrm{~min}$ at $4^{\circ} \mathrm{C}$ in the dark. Data were analyzed using FlowJo software (version 10.7.1; BD Biosciences) and the apoptotic rate was calculated as the percentage of early + late apoptotic cells.

Statistical analysis. Data were analyzed using SPSS v20.0 (IBM Corp.) and shown as mean \pm SD. Student's t-test was used to compare the difference between two groups and one-way ANOVA followed by the Tukey's post hoc test was used to compare the difference between multiple groups. $\mathrm{P}<0.05$ was considered to indicate a statistically significant difference.

\section{Results}

SIRT3 expression decreases in the bronchial tissues of the asthmatic mice. First, an asthma model was established through OVA sensitization induction, as represented in Fig. 1A. Symptoms such as sneezing, irritability, shortness of breath and scratching of the ears were observed in the asthma model mice after aerosolization. At the same time, DEX treatment could relieve the above symptoms, which indicated that the performance of the C57BL/6 as an asthma mice model after the challenge was consistent with the acute attack of asthma. Airway hyperresponsiveness (AHR) is a critical indicator of asthma and LR was used, which can reflect AHR to a certain extent, to represent AHR (37). As shown in Fig. 1B, acetylcholine increased mice LR in a dose-dependent manner and DEX reduced it. Similarly, the total content of IgE in the asthmatic mice serum was significantly higher when compared with the normal mice and DEX also significantly reduced it (Fig. 1C). Therefore, these results indicated that a mice asthma model had been successfully established.

Sirtuins, a group of class III deacetylases, have gained considerable attention for their positive effects on age-related diseases, such as cancer, cardiovascular disease, neurodegenerative diseases, osteoporosis and chronic obstructive pulmonary disease (15). SIRT3 serves an essential role in the sirtuin protein family and is also involved in mediating inflammation $(14,38)$. As a disease with chronic airway inflammation as the primary clinical symptom, the present study found that the expression of SIRT3 mRNA was significantly lower in the bronchial tissues of asthmatic mice compared with the control (Fig. 2A). Similarly, the results of SIRT3 protein detection using western blotting (Fig. 2B and C) and immunochemistry (Fig. 2D) indicated that SIRT3 expression was significantly lower in bronchial tissues of asthmatic mice compared with the control. However, it was also found that DEX treatment could not change the decreased SIRT3 expression in the bronchial tissues of asthmatic mice (Fig. 2). Taken together, SIRT3 expression decreased in the bronchial tissues of asthmatic mice.

Upregulation of SIRT3 reduces the bronchial epithelial cell apoptosis in the asthmatic mice. As a mitochondrial protein, SIRT3-mediated mitophagy protects tumor cells against apoptosis under hypoxia (28) and the loss of SIRT3 promotes the apoptosis of EC9706 cells (27). This indicates that the loss of SIRT3 promotes apoptosis. It was hypothesized that the loss of SIRT3 was also involved in regulating the apoptosis of bronchial epithelial cells in asthmatic mice. To test this hypothesis, bronchial tissues were collected from the mice 
A

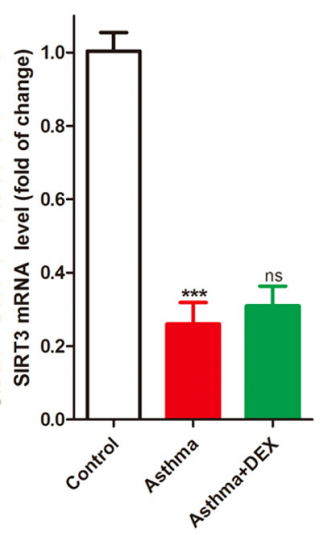

B

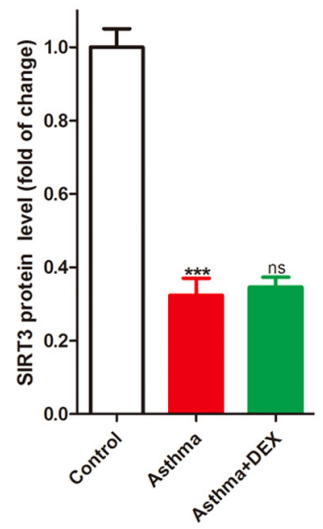

C

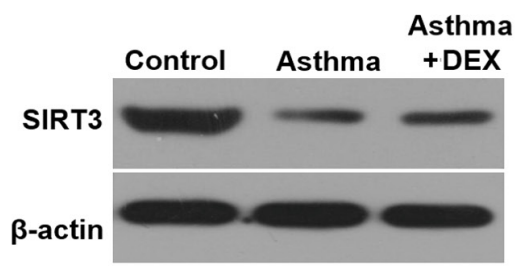

D Control Asthma Asthma+DEX
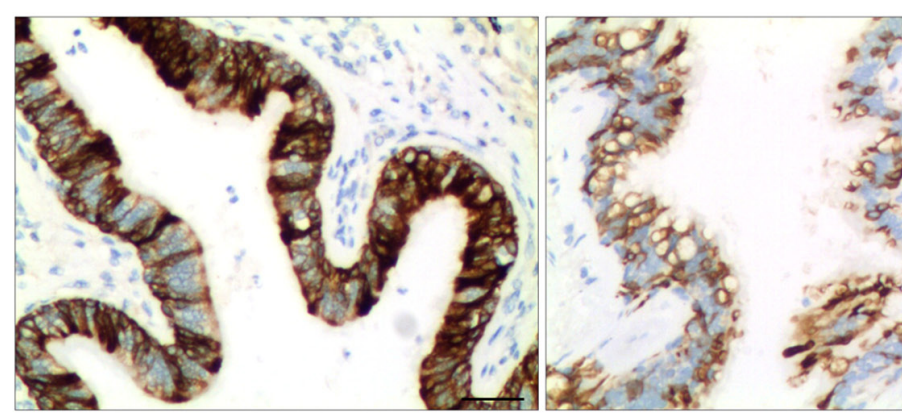

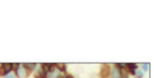

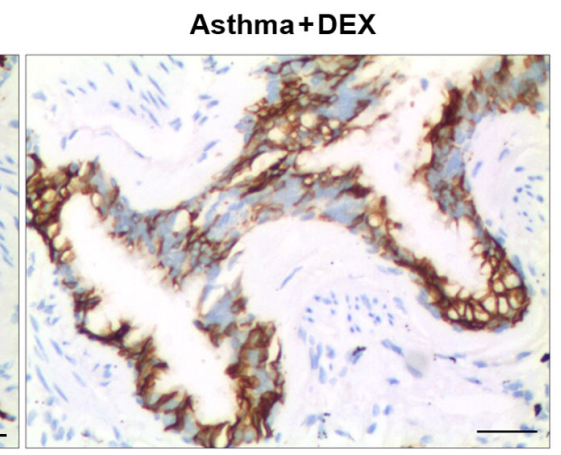

Figure 2. Expression of SIRT3 in bronchial tissues of asthmatic mice. The expression of SIRT3 in bronchial tissues of each group was detected by (A) reverse transcription-quantitative PCR, (B and C) western blotting and (D) immunochemistry (scale bar, $100 \mu \mathrm{m}$ ). There were seven mice in each group, the data were shown as mean $\pm \mathrm{SD}$ and the P-value was calculated by calculated by post-hoc comparisons. ${ }^{* * *} \mathrm{P}<0.001$ vs. control; ns, $\mathrm{P}>0.05$ vs. Asthma group. SIRT3, sirtuin 3; DEX, dexamethasone.

and apoptosis detected using TUNEL staining. It was found that the apoptotic (TUNEL positive) cells in bronchial tissue of asthmatic mice were significantly higher compared with the control mice (Fig. 3A and B). The results of the western blotting (Fig. 3C) demonstrated that Bax (a pro-apoptotic protein) protein expression levels in the asthma group were markedly higher compared with the control group, whereas $\mathrm{Bcl} 2$ (an anti-apoptotic protein) protein expression levels in the asthma group were markedly lower compared with the control group. SIRT3 protein expression levels were also markedly increased in the asthma group compared with the control group (Fig. 3D). The ratio of Bax/Bcl2 was significantly increased (Fig. 3E) in the bronchial tissues of asthmatic mice. Simultaneously, the caspase 3 activity in the bronchial tissues of asthmatic mice was significantly higher than in normal mice (Fig. 3F). To study the effect of SIRT3 expression on the apoptosis of bronchial epithelial cells in asthmatic mice, the expression of SIRT3 was upregulated using adenovirus overexpressing SIRT3 (Ad-m-SIRT3). It was found that Ad-m-SIRT3 successfully increased the expression of SIRT3 protein in bronchial tissues of asthmatic mice. Notably, overexpression of SIRT3 significantly reduced the increased TUNEL positive cells in bronchia from asthmatic mice and significantly reduced the increased $\mathrm{Bax} / \mathrm{Bcl} 2$ ratio and caspase 3 activity in the bronchia from asthmatic mice (Fig. 3). In conclusion, upregulation of SIRT3 reduced bronchial epithelial cell apoptosis in asthmatic mice.

Inflammation in BALF of the asthmatic mice is suppressed by SIRT3 overexpression. SIRT3 is an essential molecule in inflammation regulation and was previously found to attenuate palmitate-induced ROS production and inflammation in proximal tubular cells (14). In the present study, the number of immune cells (macrophages, eosinophils, lymphocytes and neutrophils) in BALF from asthmatic mice increased significantly (Fig. 4A). The cytokines expression in BALF, such as TNF- $\alpha$, IL-4, IL-5 and IL-13, was analyzed and it was found that the mRNAs of all these cytokines were also increased in BALF from asthmatic mice (Fig. 4B). Similarly, the ELISA results revealed that the content of TNF- $\alpha$, IL-4, IL-5 and IL-13 in BALF from asthmatic mice were significantly higher compared with the BALF from normal mice (Fig. 4C). To study the effect of SIRT3 expression on BALA inflammation in asthmatic mice, the expression of SIRT3 was upregulated using adenovirus overexpressing SIRT3 (Ad-m-SIRT3). The results showed that overexpression of SIRT3 not only significantly reduced the increased number of immune cells (macrophages, eosinophils, lymphocytes and neutrophils) in BALF from asthmatic mice but also reduced the increased expression and content of cytokines from cells in BALF of asthmatic mice (Fig. 4). Together, these results suggested that the overexpression of SIRT3 reduced airway inflammation in asthmatic mice, which has the same effect as the specific drug DEX, which was used as a positive control, for the treatment of allergic rhinitis.

Upregulation of SIRT3 reduces the bronchial oxidative stress in the asthmatic mice. SIRT3 protects cells and inhibits inflammation by preventing oxidative stress in a number of 

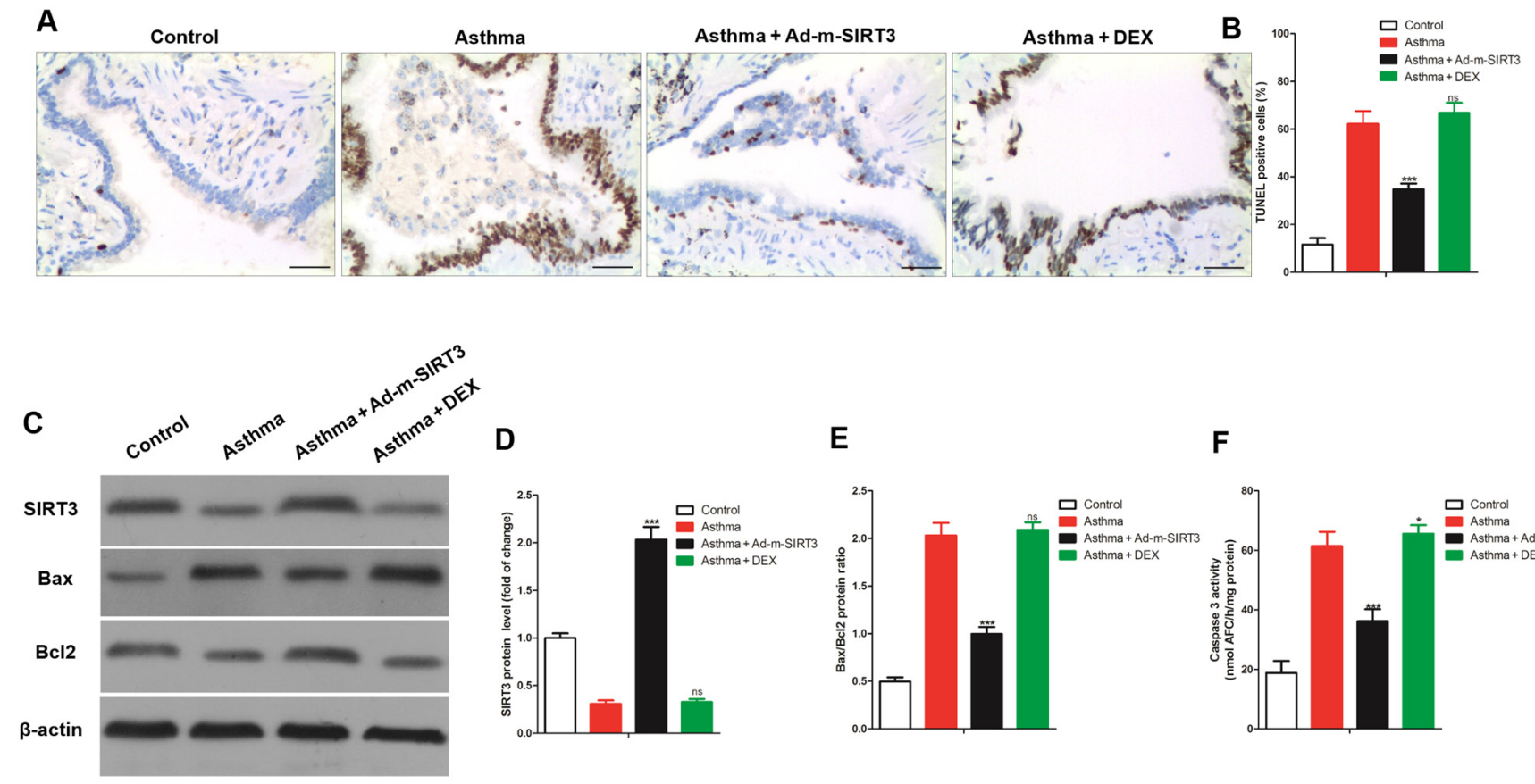

E

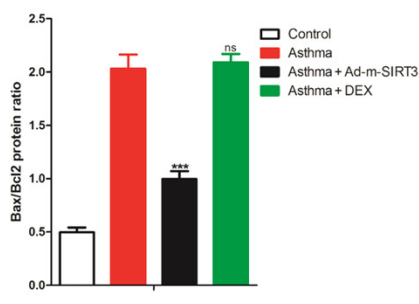

$\mathbf{F}$

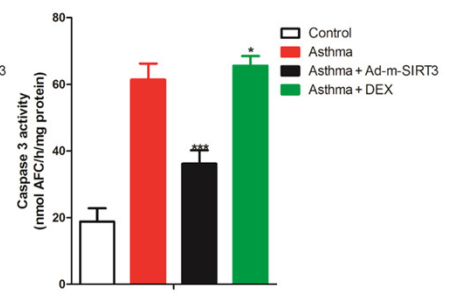

Figure 3. Increased epithelia apoptosis of bronchia in asthma is reduced by SIRT3 overexpression. (A) The representative images by TUNEL staining (scale bar, $100 \mu \mathrm{m}$ ) and (B) the statistical analysis of apoptosis in the bronchia of each group. (C) The representative band images and (D) relative band intensity analysis of SIRT3 and (E) ratio of Bax/Bcl-2. (F) The caspase-3 activity was determined in the bronchia of each group by ELISA. There were seven mice in each group, the data were shown as mean $\pm \mathrm{SD}$ and the $\mathrm{P}$-value was calculated by calculated by post-hoc comparisons. $\mathrm{ns}, \mathrm{P}>0.05,{ }^{*} \mathrm{P}>0.05$ and ${ }^{* * * *} \mathrm{P}<0.001$ vs. Asthma group. SIRT3, sirtuin 3; DEX, dexamethasone; AFC, 7-Amino-4-trifluoromethylcoumarin.

diseases, such as diabetes (39), oral cancer (40) and myocardial ischemia-reperfusion (41). Oxidative stress serves an important role in the establishment of the asthma model by OVA sensitization induction (42) and oxidative stress can cause inflammation and apoptosis $(43,44)$. Therefore, it was hypothesized that SIRT3 was involved in regulating airway inflammation and bronchial epithelial cell apoptosis by the modulation of bronchial oxidative stress in asthmatic mice. To test this hypothesis, the level of ROS was detected in the bronchial tissue by a ROS probe and it was found that the increased levels of ROS in the bronchial tissues of asthmatic mice were reduced by overexpression of SIRT3 (Fig. 5A). ELISA was used to observe the change in the endogenous antioxidants, GSH, SOD and Gpx, which are the antioxidants that help to reduce the content of ROS (45). The results of ELISA showed that the levels of GSH, SOD and Gpx in the bronchial tissues of asthmatic mice were all significantly lower compared with the control mice, while the decreased levels of GSH (Fig. 5B), SOD (Fig. 5C) and Gpx (Fig. 5D) in the bronchial tissues of asthmatic mice were reduced by overexpression of SIRT3. The levels of MDA, an indicator of the end products of the cellular membrane under oxidative injury, were detected and it was found that MDA levels increased in the bronchial tissues of asthmatic mice and overexpression of SIRT3 was able to reverse this (Fig. 5E). Therefore, these data suggested that the upregulation of SIRT3 reduced bronchial oxidative stress in the asthmatic mice.

SIRT3 regulated $\mathrm{H}_{2} \mathrm{O}_{2}$-induced apoptosis and inflammation in $16 H B E$ cells. To study the relationship between SIRT3-regulated bronchial epithelial inflammation/apoptosis and oxidative stress, an oxidative stress cell model of bronchial epithelial cells (16HBE) was established, induced by $\mathrm{H}_{2} \mathrm{O}_{2}$ in vitro. Simultaneously, SIRT3 was knocked down through SIRT3-shRNA adenovirus infection and NC-shRNA adenovirus used as a negative control; SIRT3 was overexpressed through SIRT3-AAV adenovirus infection and the NC-AAV adenovirus used as a negative control. SIRT3-shRNA successfully knocked down SIRT3 expression and SIRT3-AAV successfully overexpressed SIRT3 in 16HBE cells (Fig. 6A). Subsequently, the induction concentration of $\mathrm{H}_{2} \mathrm{O}_{2}$ was analyzed and it was found that it induced the $16 \mathrm{HBE}$ cell apoptosis in a dose-dependent manner (Fig. 6B). The $100 \mu \mathrm{mol} / 1$ $\mathrm{H}_{2} \mathrm{O}_{2}$ dosage was chosen as the induction concentration since this concentration could induce a cell apoptosis rate of $30 \%$. After stimulating with $100 \mu \mathrm{mol} / 1 \mathrm{H}_{2} \mathrm{O}_{2}$ for $12 \mathrm{~h}, 16 \mathrm{HBE}$ cells were collected to analyze the apoptosis using flow cytometry. The results revealed that the knockdown of SIRT3 significantly increased $\mathrm{H}_{2} \mathrm{O}_{2}$-induced apoptosis and overexpression of SIRT3 significantly decreased $\mathrm{H}_{2} \mathrm{O}_{2}$-induced apoptosis in the 16HBE cells (Fig. 6C and D). Knockdown of SIRT3 significantly increased the $\mathrm{H}_{2} \mathrm{O}_{2}$-induced expression of cytokines (TNF- $\alpha$, IL-4, IL-5 and IL-13) and the overexpression of SIRT3 significantly decreased the expression of these cytokines in 16HBE cells (Fig. 6E).

\section{Discussion}

The characteristics of an ideal asthma animal model include sudden onset of spasm, the occurrence of immediate and delayed allergies, airway hyperresponsiveness, chronic airway remodeling and lung function degradation $(46,47)$. Previous studies have shown that OVA sensitization induction can establish this ideal asthma animal model $(46,47)$. 

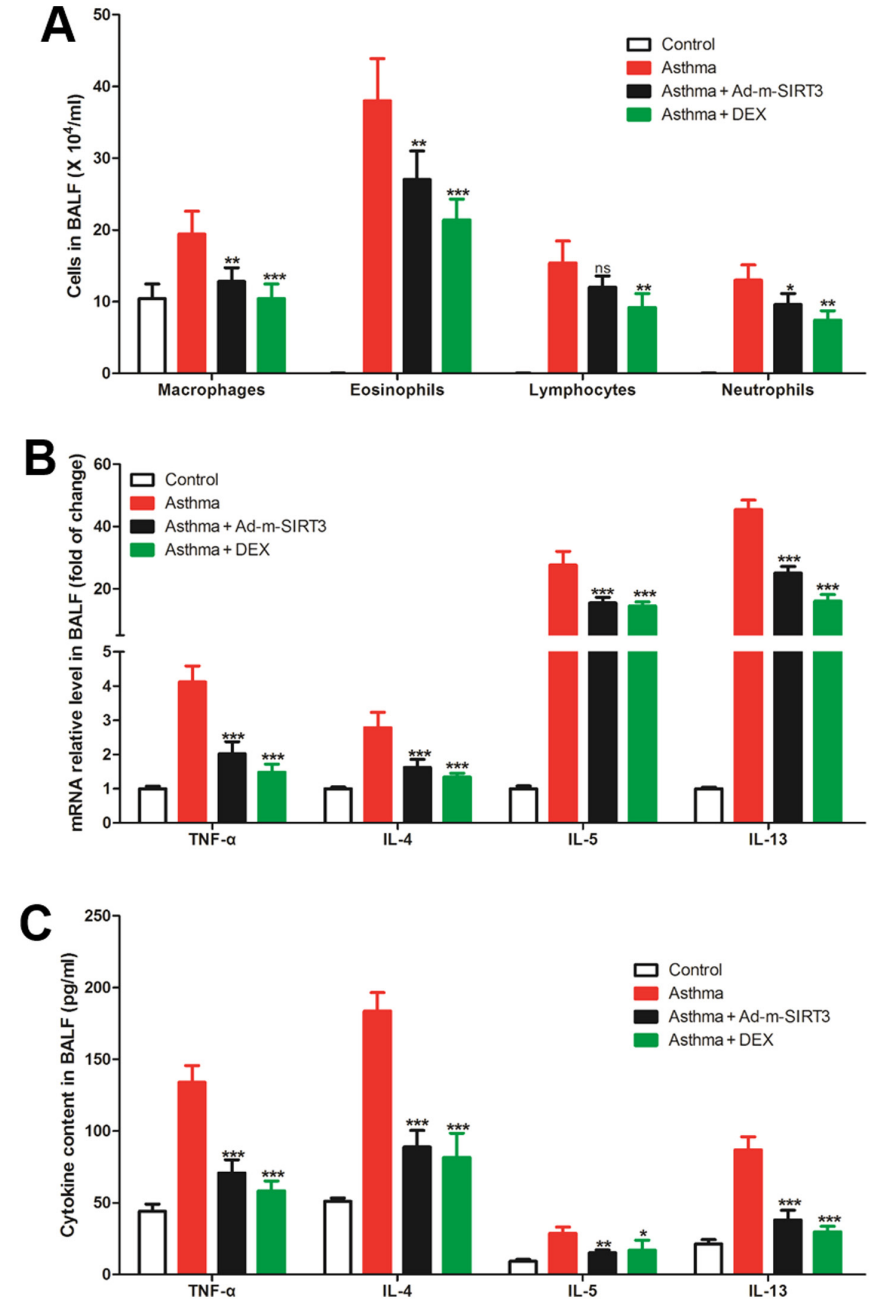

Figure 4. Upregulation of SIRT3 reduced increased inflammation of BALF in asthmatic mice. (A) The number of cells in BALF as determined by Wright's Giemsa staining. (B) The expression of cytokines (TNF- $\alpha$, IL- 4 , IL-5 and IL-13) mRNA in cells of BALF determined by reverse transcription-quantitative PCR. (C) The secretion levels of cytokines (TNF- $\alpha$, IL-4, IL-5 and IL-13) in BALF determined with ELISA assay. DEX treatment was used as the positive control. There were seven mice in each group, the data were shown as mean \pm SD and the P-value was calculated by calculated by post-hoc comparisons. ns, $\mathrm{P}>0.05,{ }^{*} \mathrm{P}>0.05,{ }^{* * *} \mathrm{P}<0.01$ and ${ }^{* * * *} \mathrm{P}<0.001$ vs. Asthma group. SIRT3, sirtuin 3; BALF, bronchoalveolar lavage fluid; DEX, dexamethasone.

The present study established an asthma model through OVA sensitization and determined the expression of the SIRT3 gene by RT-qPCR, western blotting and immunochemistry. All the results suggested that SIRT3 expression was significantly decreased in the bronchia of asthma mice and was significantly associated with the pathologic features of asthma. Notably, upregulation of SIRT3 in the bronchial tissues could reduce the increased apoptosis of bronchial epithelial cells and significantly decrease the elevated airway inflammation in asthmatic mice. In addition, upregulation of SIRT3 reduced bronchial oxidative stress in asthmatic mice. In vitro, SIRT3 was found to regulate $\mathrm{H}_{2} \mathrm{O}_{2}$-induced apoptosis and inflammation in 16HBE cells. Asthma is the result of the interaction between genetic and environmental factors and it is a complex pathological process involving multiple gene regulations (9). However, chronic airway inflammation, abnormal apoptosis of airway epithelial cells, airway epithelial damage and repair disorders are the essential pathological basis of asthma $(48,49)$. Therefore, studies on the pathogenesis of asthma, such as chronic airway inflammation and airway epithelial cell apoptosis, might find new targets for asthma treatment.

The SIRT3 gene is located on human chromosome 11 (11p15.5) and consists of 21,902 bases. SIRT3 protein is an evolutionarily highly conserved deacetylase whose activity depends on nicotinamide adenine dinucleotide and belongs to one of the proteins in the sirtuin family. In addition to regulating the body's energy metabolism, cell aging and tumor formation, SIRT3 also serves a pivotal role in regulating cell apoptosis through its enzymatic catalytic activity (23). However, to the best of the authors' knowledge, no data exist concerning the influence of SIRT3 on airway epithelial cell apoptosis. The present study found that the upregulation of SIRT3 in bronchial tissues could reduce the increased apoptosis of bronchial epithelial cells; however, the corresponding mechanism remains to be elucidated. Based on the antioxidant function of SIRT3 (50), it was hypothesized that SIRT3 might resist apoptosis by inhibiting oxidation. It was later found that the upregulation of SIRT3 reduced bronchial oxidative stress in asthmatic mice and reduced the $\mathrm{H}_{2} \mathrm{O}_{2}$-induced apoptosis in the 16HBE cells in vitro, while the loss of SIRT3 promoted $\mathrm{H}_{2} \mathrm{O}_{2}$-induced apoptosis in the $16 \mathrm{HBE}$ cells.

The body produces a large number of free radicals in metabolism and ROS are the main components. Under normal conditions, the level of ROS in the body maintains a dynamic balance, but this balance is broken by endogenous or exogenous harmful stimuli, resulting in a large amount of ROS accumulating in the body, destroying the balance between the oxidative system and the antioxidant system, developing oxidative stress and causing cell oxidative damage or apoptosis $(51,52)$. It has been confirmed that oxidative stress is closely related to cell apoptosis and ROS serves a vital role in this process $(51,52)$. A previous study has shown that ROS can activate nuclear transcription factor $\mathrm{NF}-\kappa \mathrm{B}$ leading to cell apoptosis by activating proteinase $\mathrm{C}$ (53). ROS can also activate the P53-induced apoptosis pathway by damaging DNA (54) and can also lead to cell apoptosis by damaging mitochondria and initiating the mitochondrial-mediated apoptosis pathways (39). In brief, inhibiting the generation of ROS and/or increasing the body's ability to eliminate it will inhibit cell apoptosis to some extent. Notably, SIRT3 is closely related to oxidative stress: Fu et al (50) and Zhang et al (55) confirmed that the activity of Mn-SOD in the liver of SIRT3 knockout mice is reduced and SIRT3 can significantly enhance the activity of Mn-SOD by reducing the acetylation levels of K53 and K89 or by deacetylating the 122 lysine group of Mn-SOD, thereby reducing the ROS levels in the cells.

It is hypothesized that in the pathogenesis of asthma, the ratio or functional imbalance of T helper (Th) 1 and Th2 cells, especially the increase of Th2 cells hyperfunction, are important immunological abnormal factors (56). Th2 cells mainly secrete IL-4, IL-5, IL-13 and other cytokines and mediate the occurrence of asthma through multiple pathways, such as efficient recruitment and activation of eosinophils, stimulation of Ig conversion to produce IgE and others (57). TNF- $\alpha$ is a pro-inflammatory cytokine that participates in the immune and inflammatory responses and can mediate the elevation of several inflammatory cell numbers such as eosinophils and 

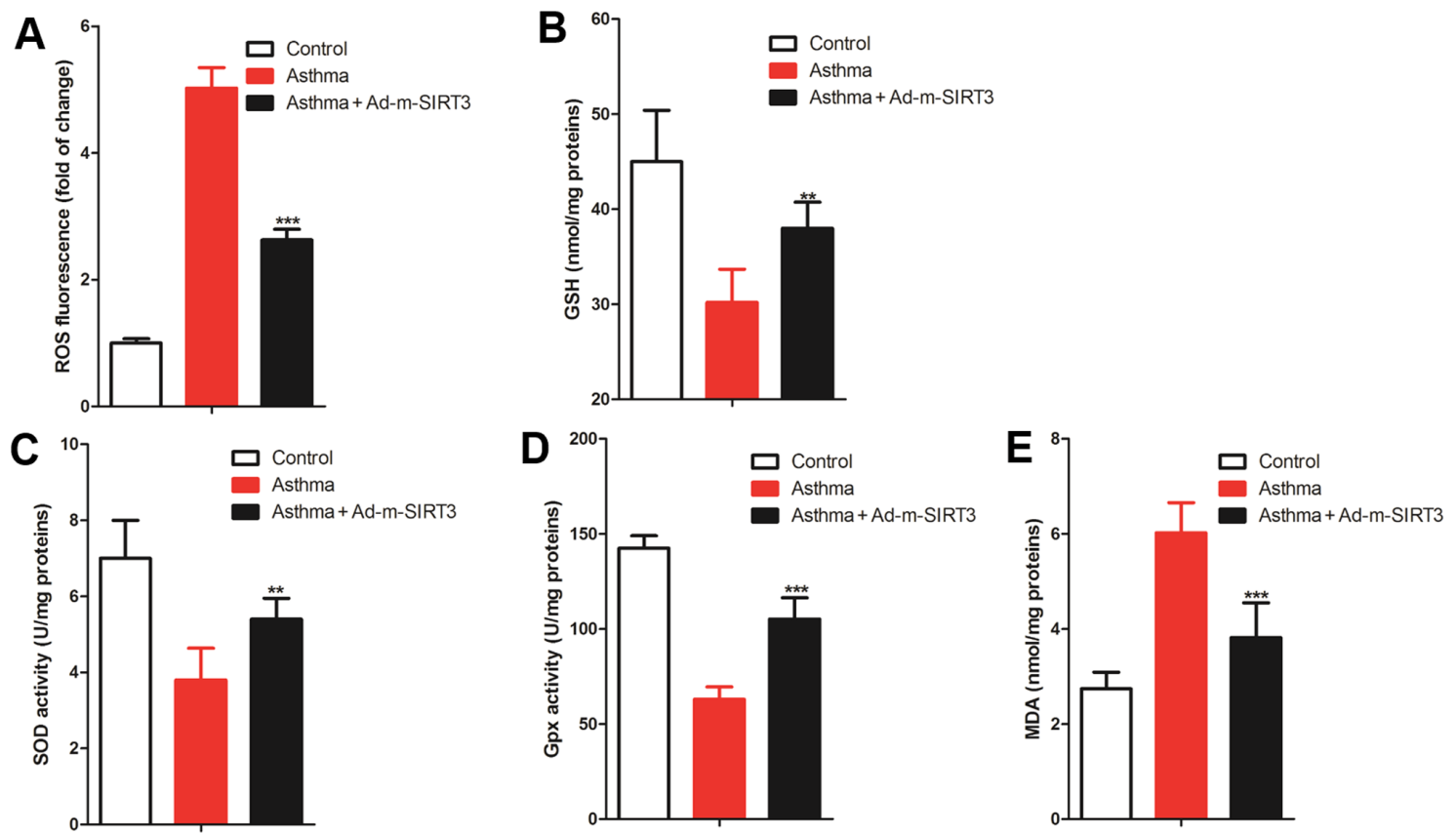

Figure 5. SIRT3 regulated redox balance in bronchial tissues of asthmatic mice. (A) ROS probe was used to observe the change in ROS in bronchial and the relative fluorescence intensity was used to quantify ROS levels. (B-D) ELISA was used to observe the change in cellular antioxidants [(B) GSH, (C) SOD and (D) Gpx]. (E) MDA, the end product of the cellular membrane under oxidative injury, was detected by ELISA. There were seven mice in each group, the data were shown as mean $\pm \mathrm{SD}$ and the $\mathrm{P}$-value was calculated by Student's t-test. ${ }^{* *} \mathrm{P}<0.01$ and ${ }^{* * *} \mathrm{P}<0.001$ vs. Asthma group. SIRT3, sirtuin 3 ; ROS, reactive oxygen species; GSH, glutathione; SOD, superoxide dismutase; Gpx, glutathione peroxidase; MDA, malondialdehyde.
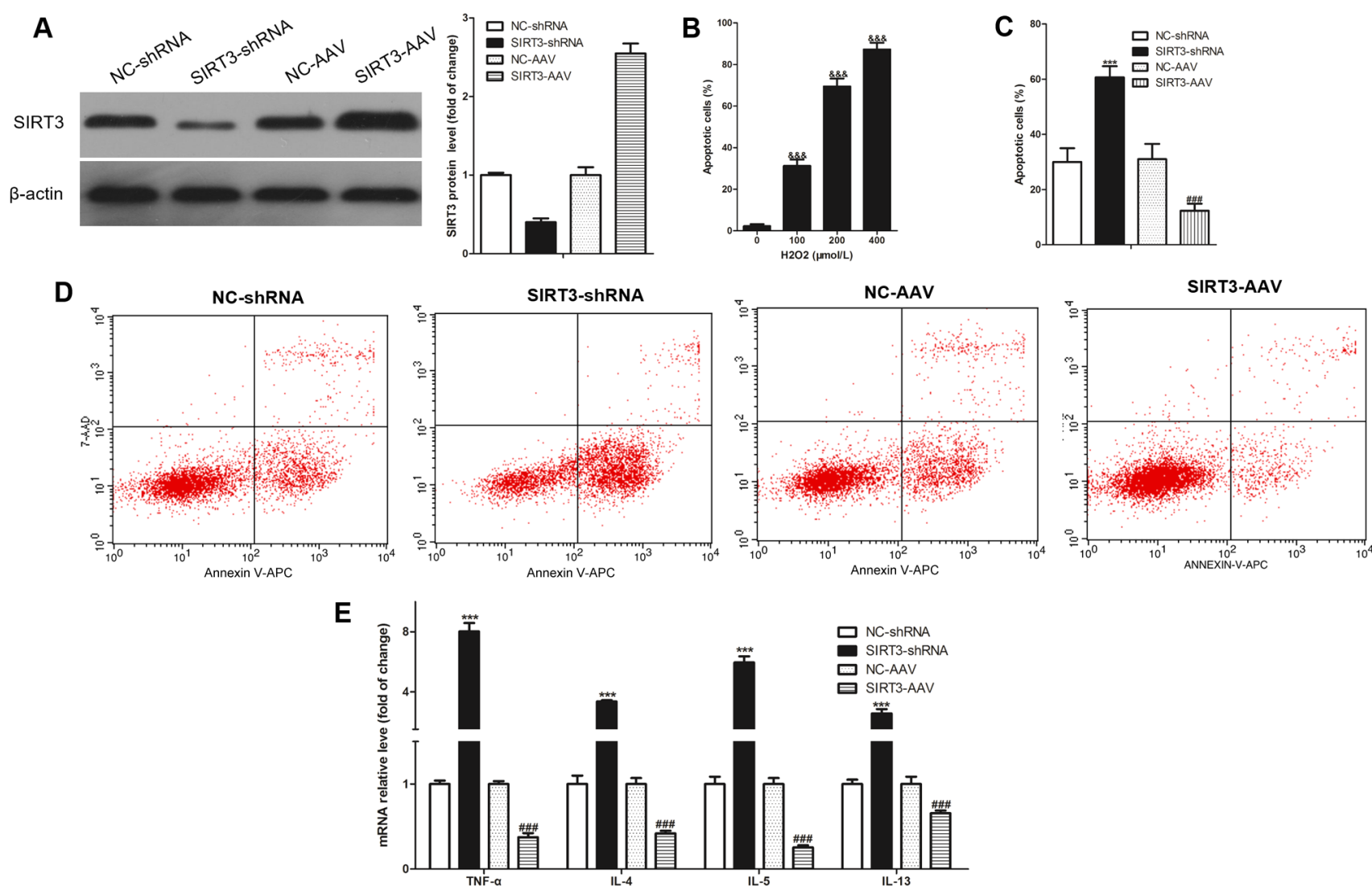

Figure 6. SIRT3 reduced apoptosis and inflammation caused by oxidative stress in 16HBE cells. (A) Western blotting was used to detected the expression of SIRT3 in 16HBE cells of each group. (B) Following stimulation with different concentrations of $\mathrm{H}_{2} \mathrm{O}_{2}$ for $12 \mathrm{~h}$, flow cytometry was used to analyze apoptosis (C and D) After stimulating with $100 \mu \mathrm{mol} / 1 \mathrm{H}_{2} \mathrm{O}_{2}$ for $12 \mathrm{~h}$, the apoptosis of $16 \mathrm{HBE}$ cells before and after the knockdown or overexpression of SIRT3 was analyzed by flow cytometry. (E) The expression of cytokines (TNF- $\alpha$, IL-4, IL-5 and IL-13) mRNA was detected by reverse transcription-quantitative PCR. Each experiment was repeated three times and data were shown as mean $\pm \mathrm{SD}$. The P-values were calculated by calculated by Student's t-test in A, C and $\mathrm{E}$ and by post-hoc comparisons in $\mathrm{B} .{ }^{* * * *} \mathrm{P}<0.001$ vs. NC-shRNA group; ${ }^{\# \# \#} \mathrm{P}<0.001$ vs. NC-AAV group; and ${ }^{\text {\&\&\& }} \mathrm{P}<0.001$ vs. $0 \mu \mathrm{mol} / 1 \mathrm{H}_{2} \mathrm{O}_{2}$. SIRT3, sirtuin 3 ; sh, short hairpin; $\mathrm{NC}$, negative control. 
neutrophils, generate a variety of inflammatory mediators and aggravate the inflammatory response $(58,59)$. TNF- $\alpha$ can also stimulate endothelial cells and macrophages to release IL-6 and other inflammatory mediators, causing airway inflammation, destroying collagen networks and participating in airway remodeling $(60,61)$. In asthma, TNF- $\alpha$ expression in the airways and lungs is significantly increased, promoting the occurrence and development of inflammatory reactions $(60,61)$. Inflammation and oxidative stress are not independent of each other $(62,63)$ : Inflammation can cause oxidative stress and oxidative stress can also cause inflammation, including oxidative stress-induced airway inflammation (64). In a number of previous studies, a cell oxidative stress induced by $\mathrm{H}_{2} \mathrm{O}_{2}$ model was used to study inflammation, such as Cao et al (65) and de Oliveira-Marques et al (66), including $\mathrm{H}_{2} \mathrm{O}_{2}$-induce $16 \mathrm{HBE}$ cells (67). The results of the present study suggested that the upregulation of SIRT3 could decrease the elevated airway inflammation in asthmatic mice and reduce the $\mathrm{H}_{2} \mathrm{O}_{2}$-induced inflammation in the $16 \mathrm{HBE}$ cells in vitro, while the loss of SIRT3 improved the $\mathrm{H}_{2} \mathrm{O}_{2}$-induced inflammation in the $16 \mathrm{HBE}$ cells.

To the best of the authors' knowledge, no relation has been established between SIRT3 and inflammation in the bronchial tissue in asthma. However, the study of SIRT3 inhibiting inflammation has been widely reported: Koyama et al (14) found that SIRT3 attenuates palmitate-induced ROS production and inflammation in proximal tubular cells and Boniakowski et al (38) describes that SIRT3 suppresses macrophage-mediated inflammation in diabetic wound repair. The findings of the present study shared broad similarities with an earlier study by Kim et al (68) who report that KIF3A deficiency in mice results in increased inflammation. Thus, it was hypothesized that decreased expression of SIRT3 in the bronchial epithelium of asthmatic animals may modulate the airway inflammation, which needs further validation and support. In conclusion, the results of the present study indicated that the SIRT3 gene may be a key molecule for targeted therapeutics for asthma. However, the lack of data on SIRT3 expression in clinical studies is limited and therefore needs to be explored in future work.

\section{Acknowledgements}

Not applicable.

\section{Funding}

No funding was received.

\section{Availability of data and materials}

The datasets used and/or analyzed during the current study are available from the corresponding author on reasonable request.

\section{Authors' contributions}

JS conceived the study, wrote the manuscript, performed the data analysis, participated in the experiments and data collection. JW designed and supervised the study and edited the manuscript. JS and JW confirm the authenticity of all the raw data. All authors read and approved the final manuscript.

\section{Ethics approval and consent to participate}

The present study was approved by the Beijing Luhe Hospital, Capital Medical University (Tongzhou, China; approval no. 2021-LHKY-055-02).

\section{Patient consent for publication}

Not applicable.

\section{Competing interests}

The authors declare that they have no competing interests.

\section{References}

1. Boulet LP, Reddel HK, Bateman E, Pedersen S, FitzGerald JM and O'Byrne PM: The global initiative for asthma (GINA): 25 years later. Eur Respir J 54: 1900598, 2019.

2. Lin J, Wang W, Chen P, Zhou X, Wan H, Yin K, Ma L, Wu C, Li J, Liu C, et al: Prevalence and risk factors of asthma in mainland China: The CARE study. Respir Med 137: 48-54, 2018.

3. Lambrecht BN, Hammad H and Fahy JV: The cytokines of asthma. Immunity 50: 975-991, 2019.

4. Pavord ID, Beasley R, Agusti A, Anderson GP, Bel E, Brusselle G, Cullinan P, Custovic A, Ducharme FM, Fahy JV, et al: After asthma: Redefining airways diseases. Lancet 391: 350-400, 2018.

5. Heffler E, Madeira LNG, Ferrando M, Puggioni F, Racca F, Malvezzi L, Passalacqua G and Canonica GW: Inhaled corticosteroids safety and adverse effects in patients with asthma. J Allergy Clin Immunol Pract 6: 776-781, 2018.

6. Kato A and Schleimer RP: Beyond inflammation: Airway epithelial cells are at the interface of innate and adaptive immunity. Curr Opin Immunol 19: 711-720, 2007.

7. Hiemstra PS, McCray PB Jr and Bals R: The innate immune function of airway epithelial cells in inflammatory lung disease. Eur Respir J 45: 1150-1162, 2015.

8. Lopez-Guisa JM, Powers C, File D, Cochrane E, Jimenez N and Debley JS: Airway epithelial cells from asthmatic children differentially express proremodeling factors. J Allergy Clin Immunol 129: 990-997.e6, 2012.

9. Haddad A, Gaudet M, Plesa M, Allakhverdi Z, Mogas AK, Audusseau S, Baglole CJ, Eidelman DH, Olivenstein R, Ludwig MS and Hamid Q: Neutrophils from severe asthmatic patients induce epithelial to mesenchymal transition in healthy bronchial epithelial cells. Respir Res 20: 234, 2019.

10. Wątroba M, Dudek I, Skoda M, Stangret A, Rzodkiewicz P and Szukiewicz D: Sirtuins, epigenetics and longevity. Ageing Res Rev 40: 11-19, 2017.

11. Ma K, Lu N, Zou F and Meng FZ: Sirtuins as novel targets in the pathogenesis of airway inflammation in bronchial asthma. Eur J Pharmacol 865: 172670, 2019.

12. Liu TF, Vachharajani V, Millet P, Bharadwaj MS, Molina AJ and Mccall CE: Sequential actions of SIRT1-RELB-SIRT3 coordinate nuclear-mitochondrial communication during immunometabolic adaptation to acute inflammation and sepsis. J Biol Chem 290: 396-408, 2015.

13. Ren JH, Xiang C, Li Z, Tao NN, Zhou HZ, Liu B, Li WY, Huang AL and Chen J: Protective role of sirtuin3 (SIRT3) in Oxidative stress mediated by hepatitis $\mathrm{B}$ virus $\mathrm{X}$ protein expression. PLoS One 11: e0150961, 2016.

14. Koyama T, Kume S, Koya D, Araki S, Isshiki K, Chin-Kanasaki M, Sugimoto T, Haneda M, Sugaya T, Kashiwagi A, et al: SIRT3 attenuates palmitate-induced ROS production and inflammation in proximal tubular cells. Free Radic Biol Med 51: 1258-1267, 2011.

15. Chun P: Role of sirtuins in chronic obstructive pulmonary disease. Arch Pharm Res 38: 1-10, 2015.

16. Kurundkar D, Kurundkar AR, Bone NB, Becker EJ Jr, Liu W, Chacko B, Darley-Usmar V, Zmijewski JW and Thannickal VJ: SIRT3 diminishes inflammation and mitigates endotoxin-induced acute lung injury. JCI Insight 4: e120722, 2019. 
17. Tian YG and Zhang J: Protective effect of SIRT3 on acute lung injury by increasing manganese superoxide dismutase-mediated antioxidation. Mol Med Rep 17: 5557-5565, 2018.

18. Zhang M, Zhang Y, Roth M, Zhang L, Shi R, Yang X, Li Y and Zhang J: Sirtuin 3 inhibits airway epithelial mitochondrial oxidative stress in cigarette smoke-induced COPD. Oxid Med Cell Longev 2020: 7582980, 2020.

19. Chen IC, Huang HH, Chen PF and Chiang HC: Sirtuin 3 protects against urban particulate matter-induced autophagy in human bronchial epithelial cells. Toxicol Sci 152: 113-127, 2016.

20. Wang Y, Li D, Ma G, Li W, Wu J, Lai T, Huang D, Zhao X, Lv Q, Chen $\mathrm{M}$ and Wu B: Increases in peripheral SIRT 1: A new biological characteristic of asthma. Respirology 20: 1066-1072, 2015.

21. Tsilogianni Z, Baker JR, Papaporfyriou A, Papaioannou AI, Papathanasiou E, Koulouris NG, Daly L, Ito K, Hillas G, Papiris S, et al: Sirtuin 1: Endocan and sestrin 2 in different biological samples in patients with asthma. Does severity make the difference? J Clin Med 9: 473, 2020.

22. Colley T, Mercado N, Kunori Y, Brightling C, Bhavsar PK, Barnes PJ and Ito K: Defective sirtuin-1 increases IL-4 expression through acetylation of GATA-3 in patients with severe asthma. J Allergy Clin Immunol 137: 1595-1597. e7, 2016.

23. Giralt A and Villarroya F: SIRT3, a pivotal actor in mitochondrial functions: Metabolism, cell death and aging. Biochem J 444: 1-10, 2012.

24. Roscioli E, Hamon R, Ruffin RE, Lester S and Zalewski P: Cellular inhibitor of apoptosis-2 is a critical regulator of apoptosis in airway epithelial cells treated with asthma-related inflammatory cytokines. Physiol Rep 1: e00123, 2013.

25. Trautmann A, Schmid-Grendelmeier P, Krüger K, Crameri R, Akdis M, Akkaya A, Bröcker EB, Blaser K and Akdis CA: T cells and eosinophils cooperate in the induction of bronchial epithelial cell apoptosis in asthma. J Allergy Clin Immunol 109: 329-337, 2002

26. Jablonski RP, Kim SJ, Cheresh P, Williams DB Morales-Nebreda L, Cheng Y, Yeldandi A, Bhorade S, Pardo A, Selman M, et al: SIRT3 deficiency promotes lung fibrosis by augmenting alveolar epithelial cell mitochondrial DNA damage and apoptosis. FASEB J 31: 2520-2532, 2017.

27. Yang M, Yang C and Pei Y: Effects of downregulation of SIRT3 expression on proliferation and apoptosis in esophageal squamous cell carcinoma EC9706 cells and its molecular mechanisms. Biomed Mater Eng 24: 3883-3890, 2014.

28. Qiao A, Wang K, Yuan Y, Guan Y, Ren X, Li L, Chen X, Li F, Chen AF, Zhou J, et al: Sirt3-mediated mitophagy protects tumor cells against apoptosis under hypoxia. Oncotarget 7 : 43390-43400, 2016

29. Luo X, Yang Z, Zheng S, Cao Y and Wu Y: Retracted: Sirt3 activation attenuated oxidized low-density lipoprotein-induced human umbilical vein endothelial cells' apoptosis by sustaining autophagy. Cell Biol Int 41: 932, 2017.

30. Jiao X, Li Y, Zhang T, Liu M and Chi Y: Role of Sirtuin3 in high glucose-induced apoptosis in renal tubular epithelial cells. Biochem Biophys Res Commun 480: 387-393, 2016.

31. Geng G, Du Y, Dai J, Tian D, Xia Y and Fu Z: KIF3A knockdown sensitizes bronchial epithelia to apoptosis and aggravates airway inflammation in asthma. Biomed Pharmacother 97: 1349-1355, 2018

32. Yilmaz O, Karaman M, Bagriyanik HA, Firinci F, Kiray M, Turkeli A, Karaman O and Yuksel H: Comparison of TNF antagonism by etanercept and dexamethasone on airway epithelium and remodeling in an experimental model of asthma. Int Immunopharmacol 17: 768-773, 2013

33. Yang C, Li J, Lin H, Zhao K and Zheng C: Nasal mucosa derived-mesenchymal stem cells from mice reduce inflammation via modulating immune responses. PLoS One 10: e0118849, 2015

34. Karra L, Haworth O, Priluck R, Levy BD and Levi-Schaffer F Lipoxin $\mathrm{B}_{4}$ promotes the resolution of allergic inflammation in the upper and lower airways of mice. Mucosal Immunol 8: 852-862, 2015.

35. Livak KJ and Schmittgen TD: Analysis of relative gene expression data using real-time quantitative PCR and the 2(-Delta Delta C(T)) method. Methods 25: 402-408, 2001.

36. Hu J, Zhang G and Selzer ME: Activated caspase detection in living tissue combined with subsequent retrograde labeling, immunohistochemistry or in situ hybridization in whole-mounted lamprey brains. J Neurosci Methods 220: 92-98, 2013.

37. Wang H, Liu Y, Shi J and Cheng Z: ORMDL 3 knockdown in the lungs alleviates airway inflammation and airway remodeling in asthmatic mice via JNK1/2-MMP-9 pathway. Biochem Biophys Res Commun 516: 739-746, 2019.
38. Boniakowski AE, denDekker AD, Davis FM, Joshi A, Kimball AS, Schaller M, Allen R, Bermick J, Nycz D, Skinner ME, et al: SIRT3 regulates macrophage-mediated inflammation in diabetic wound repair. J Invest Dermatol 139: 2528-2537.e2, 2019.

39. Zheng J, Shi L, Feng L, Xu W, Li T, Gao L, Sun Z, Yu J and Zhang J: Sirt3 ameliorates oxidative stress and mitochondrial dysfunction after intracerebral hemorrhage in diabetic rats. Front Neurosci 12: 414, 2018.

40. Kao YY, Chou CH, Yeh LY, Chen YF, Chang KW, Liu CJ, Fan Chiang CY and Lin SC: MicroRNA miR-31 targets SIRT3 to disrupt mitochondrial activity and increase oxidative stress in oral carcinoma. Cancer Lett 456: 40-48, 2019.

41. Chang G, Chen Y, Zhang H and Zhou W: Trans sodium crocetinate alleviates ischemia/reperfusion-induced myocardial oxidative stress and apoptosis via the SIRT3/FOXO3a/SOD2 signaling pathway. Int Immunopharmacol 71: 361-371, 2019.

42. Sahiner UM, Birben E, Erzurum S, Sackesen C and Kalayci Ö: Oxidative stress in asthma: Part of the puzzle. Pediatr Allergy Immunol 29: 789-800, 2018.

43. Mishra V, Banga J and Silveyra P: Oxidative stress and cellular pathways of asthma and inflammation: Therapeutic strategies and pharmacological targets. Pharmacol Ther 181: 169-182, 2018

44. Chandra J, Samali A and Orrenius S: Triggering and modulation of apoptosis by oxidative stress. Free Radic Biol Med 29: 323-333, 2000

45. Pisoschi AM and Pop A: The role of antioxidants in the chemistry of oxidative stress: A review. Eur J Med Chem 97: 55-74, 2015.

46. Yuk JE, Lee MY, Kwon OK, Cai XF, Jang HY, Oh SR, Lee HK and Ahn KS: Effects of astilbic acid on airway hyperresponsiveness and inflammation in a mouse model of allergic asthma. Int Immunopharmacol 11: 266-273, 2011.

47. Ji W, Chen X, Zhengrong C, Yumin H, Huang L and Qiu Y: Therapeutic effects of anti-B7-1 antibody in an ovalbumininduced mouse asthma model. Int Immunopharmacol 8: 1190-1195, 2008.

48. Xie CH, Cao YM, Huang Y, Shi QW, Guo JH, Fan ZW, Li JG, Chen BW and Wu BY: Long non-coding RNA TUG1 contributes to tumorigenesis of human osteosarcoma by sponging miR-9-5p and regulating POU2F1 expression. Tumour Biol 37: 15031-15041, 2016.

49. Marszalek JR, Liu X, Roberts EA, Chui D, Marth JD, Williams DS and Goldstein LS: Genetic evidence for selective transport of opsin and arrestin by kinesin-II in mammalian photoreceptors. Cell 102: 175-187, 2000.

50. Fu Y, Kinter M, Hudson J, Humphries KM, Lane RS, White JR, Hakim M, Pan Y, Verdin E and Griffin TM: Aging promotes sirtuin 3-dependent cartilage superoxide dismutase 2 acetylation and osteoarthritis. Arthritis Rheumatol 68: 1887-1898, 2016.

51. Loh KP, Huang SH, De Silva R, Tan BK and Zhu YZ: Oxidative stress: Apoptosis in neuronal injury. Curr Alzheimer Res 3: 327-337, 2006.

52. Lushchak VI: Free radicals, reactive oxygen species, oxidative stress and its classification. Chem Biol Interact 224: 164-175, 2014.

53. Yijing GF and Tangxue-Ming SY: Activation of Transcription Factor NF-kB and Accumulation of Reactive Oxygen Species Are Involved in Arsenic Trioxide-induced Apoptosis of Esophageal Carcinoma Cells. 5: 140-140, 2000 (In Chinese).

54. Ye J, Wang S, Leonard SS, Sun Y, Butterworth L, Antonini J, Ding M, Rojanasakul Y, Vallyathan V, Castranova V and Shi X: Role of reactive oxygen species and $\mathrm{p} 53$ in chromium(VI)-induced apoptosis. J Biol Chem 274: 34974-34980, 1999.

55. Zhang J, Song X, Cao W, Lu J, Wang X, Wang G, Wang Z and Chen X: Autophagy and mitochondrial dysfunction in adjuvant-arthritis rats treatment with resveratrol. Sci Rep 6: 32928 , 2016.

56. Riiser A: The human microbiome, asthma and allergy. Allergy Asthma Clin Immunol 11: 35, 2015.

57. Fahy JV: Type 2 inflammation in asthma-present in most, absent in many. Nat Rev Immunol 15: 57-65, 2015.

58. Almishri W, Santodomingo-Garzon T, Le T, Stack D, Mody CH and Swain MG: TNFa augments cytokine-induced NK cell IFN $\gamma$ production through TNFR2. J Innate Immun 8: 617-629, 2016.

59. Lampropoulou IT, Stangou M, Sarafidis P, Gouliovaki A, Giamalis P, Tsouchnikas I, Didangelos T and Papagianni A: TNF- $\alpha$ pathway and T-cell immunity are activated early during the development of diabetic nephropathy in type II diabetes mellitus. Clin Immunol 215: 108423,2020. 
60. Brightling $\mathrm{C}$, Berry $\mathrm{M}$ and Amrani Y: Targeting TNF-alpha: A novel therapeutic approach for asthma. J Allergy Clin Immunol 121: 5-10; quiz 11-2, 2008.

61. Berry M, Brightling C, Pavord I and Wardlaw A: TNF-alpha in asthma. Curr Opin Pharmacol 7: 279-282, 2007.

62. Tabet F and Rye KA: High-density lipoproteins, inflammation and oxidative stress. Clin Sci (Lond) 116: 87-98, 2009.

63. Yoshikawa T: Inflammation and oxidative stress. Nihon Naika Gakkai Zasshi 95: 1870-1875, 2006 (In Japanese).

64. Chen Q, Zhou Y, Zhou L, Fu Z, Yang C, Zhao L, Li S, Chen Y, $\mathrm{Wu} Y$, Ling $\mathrm{Z}$, et al: TRPC6-dependent $\mathrm{Ca}^{2+}$ signaling mediates airway inflammation in response to oxidative stress via ERK pathway. Cell Death Dis 11: 170, 2020.

65. Cao YJ, Zhang YM, Qi JP, Liu R, Zhang H and He LC: Ferulic acid inhibits $\mathrm{H} 2 \mathrm{O} 2$-induced oxidative stress and inflammation in rat vascular smooth muscle cells via inhibition of the NADPH oxidase and NF- $\kappa$ B pathway. Int Immunopharmacol 28 $1018-1025,2015$
66. de Oliveira-Marques V, Cyrne L, Marinho HS and Antunes F: A quantitative study of NF-kappaB activation by $\mathrm{H} 2 \mathrm{O} 2$ : Relevance in inflammation and synergy with TNF-alpha. J Immunol 178: 3893-3902, 2007.

67. Suwara MI, Borthwick LA, Mann J, Fisher AJ and Mann DA: Inflammation: An important Regulator of the Fibrotic Response: S120 IL-1 is a Key Epithelial Alarmin Which Oromotes Fibroblast Activation. Newcastle University, Newcastle, 2010.

68. Kim D, Park W, Lee S, Kim W, Park SK and Kang KP: Absence of Sirt3 aggravates cisplatin nephrotoxicity via enhanced renal tubular apoptosis and inflammation. Mol Med Rep 18: 3665-3672, 2018

(i) (9) This work is licensed under a Creative Commons Attribution-NonCommercial-NoDerivatives 4.0 International (CC BY-NC-ND 4.0) License. 